\title{
Assessment of knowledge of ethical and Palliative Care Issues in professionals who are working in Palliative Care.
}

\section{Villavicencio-Chávez C. ${ }^{1,2}$, Esquirol-Caussa J.1,5, Garzón-Rogríguez C. ${ }^{1,8}$, Vaquero-Cruzado J. ${ }^{1,3}$, Loncan-Vidal P. ${ }^{4}$, Guerrero-Torrelles M. ${ }^{6}$,Sánchez-} Aldeguer J. ${ }^{5}$,Garcia-Navarro Y. ${ }^{1,7}$,Garcia-Abejas A. ${ }^{1,9}$,Ortega-Carrillo A. ${ }^{1}$

\author{
1. Caredoctors, Palliative Research Team, Barcelona, Spain. \\ 2. Universitat Internacional de Catalunya, Facultad de Medicina Humana, Barcelona, Spain. \\ 3. Institut Català de la Salut, Equip de Gestió de la Cronicitat, Baix Llobregat Centre, Spain. \\ 4. Fundació Santa Susanna, Palliative Home Care Team, Caldes de Montbui, Spain. \\ 5. Fundació Privada Escoles Universitarias Gimbernat. Barcelona Spain. \\ 6. Universitat Internacional de Catalunya, Catedra WeCare, Barcelona, Spain. \\ 7. Institut Català de la Salut, EAP San Antoni, Barcelona Spain. \\ 8. Centres Blauclinic Isabel Roig. Barcelona. Spain \\ 9. José de Mello Saude. Residências e Serviços. Lisboa. Portugal.
}

Aim: To assess the knowledge of the ethical (ET) and palliative care (PC) aspects in professionals (Ps) that are working with patients $(\mathrm{Px})$ with advanced chronic disease (ACD).
Method: From June to August 2018 an ad hoc questionnaire was designed using Delphi methodology: 12 questions (6 ethical and 6 PC conceptual). Results were published online in September and disseminated through social networks. Socio-demographics (SD) were recorded including age, profession and workplace.

\section{Results}

N:128: Average age: $44.4 \pm 10.8$

\begin{tabular}{l|c}
\multicolumn{1}{c|}{ Professions } & $\%$ \\
\hline Physicians & $50.8 \%$ \\
$>$ Nurses & $32 \%$ \\
$>$ Other health professions & $17.2 \%$
\end{tabular}

\begin{tabular}{|c|c|}
\hline Workplace & $\%$ \\
\hline$>$ Hospital & $28.9 \%$ \\
\hline$>$ Primary care & $21.1 \%$ \\
\hline$>$ Nursing home & $13.3 \%$ \\
\hline$>$ Intermediate care & $18 \%$ \\
\hline
\end{tabular}

\section{Palliative Care (PC) aspects}

* PC assessment included physical, emotional, social and spiritual dimensions

$77.3 \%$

$98.4 \%$

$46.4 \%$

$81.9 \%$

$97.6 \%$

$83.6 \%$.

Believed family members should be informed that the patient in agony does not perceive suffering

\section{Ethically Aspects}

* Consider as a wrong that, in the EOL period prevails the opinion of the doctor over the patient and family opinions.

* The ethical criterion to decide the treatments in a non-autonomous patient, should be the duty of care of the Px as part of the community.

* Recognized advance directives document is not the same as the advance care planning

* The autonomy of the patient should be respected and their preferences should be assessed in the face of a disease situation.

* The euthanasia is direct, active and voluntary

* Endorsed constant monitoring of symptom control and emotional support to the family of Px. in EOL.

$86.7 \%$

$77.8 \%$

$58.6 \%$

$94.3 \%$

$81.9 \%$

$99.2 \%$

Conclusions: Our overall scores support that Ps are aware of many ET and PC issues of patients of ACD. Yet they also raise the possibility that a considerable number of Ps could need further education in ET and PC issues. 